\title{
Hypochlorite solution for root canal irrigation that lacks a chlorinated odor
}

\author{
La-ongthong Vajrabhaya ${ }^{1}$, Vanida Sangalungkarn ${ }^{2}$, Ratchapin Srisatjaluk ${ }^{3}$, \\ Suwanna Korsuwannawong ${ }^{4}$, Chareerut Phruksaniyom ${ }^{2}$
}

Correspondence: Dr. Vanida Sangalungkarn

Email: vanida.san@mahidol.ac.th

\author{
'Endodontic Section, Faculty of Dental Medicine, \\ Rangsit University, Pathum Thani, Thailand, \\ 2Department of Pharmacology, Faculty of Dentistry, \\ Mahidol University, Bangkok, Thailand, \\ ${ }^{3}$ Department of Microbiology, Faculty of Dentistry, \\ Mahidol University, Bangkok, Thailand, \\ ${ }^{4}$ Research Office, Faculty of Dentistry, Mahidol \\ University, Bangkok, Thailand
}

\section{ABSTRACT}

Objectives: This is an in vitro study to develop a formulation of a hypochlorite solution for root canal irrigation that lacks a chlorinated odor. The antibacterial effect, tissue dissolution efficacy, and the cytotoxicity of the solution were assessed in cell culture and were compared with those of commercial sodium hypochlorite ( $\mathrm{NaOCl}$ ) solutions. Materials and Methods: Trichloroisocyanuric acid (TCA) was used as the source of hypochlorite ions in solution. All required properties of the $\mathrm{NaOCl}$ irrigant were evaluated and compared with those of original $2.5 \% \mathrm{NaOCl}$ solutions currently in use. Results: Our results revealed that a TCA 3.5\% + 1/6 Buffer-1 solution passed the short-term stability test. Moreover, no odor of chlorine gas was detected by three independent observers. The hypochlorite ion content and $\mathrm{pH}$ were stable over an incubation period of 4 weeks. The new solution did not differ from commercial products in terms of the dissolution property on bovine pulpal tissue $(P>0.05)$. Moreover, the antibacterial effect of this solution on Enterococcus faecalis did not differ from that of the commercial products $(P>0.05)$. In addition, our biocompatibility analysis demonstrated no difference among the tested solutions $(P>0.05)$. Conclusions: According to the results of all properties tested, TCA $3.5 \%+1 / 6$ Buffer- 1 could be considered an option for $\mathrm{NaOCl}$ irrigation with the benefit of no detectable chlorine odor.

Key words: Hypochlorite solution, lacks a chlorinated odor, root canal irrigant

\section{INTRODUCTION}

Elimination of inflammatory or necrotic pulpal tissue is the primary aim of root canal treatment. Sodium hypochlorite $(\mathrm{NaOCl})$ is extensively used as a root canal irrigant for root canal disinfection. Antibacterial infection and necrotic pulpal tissue dissolution are the two main purposes of root canal irrigants. ${ }^{[1]}$

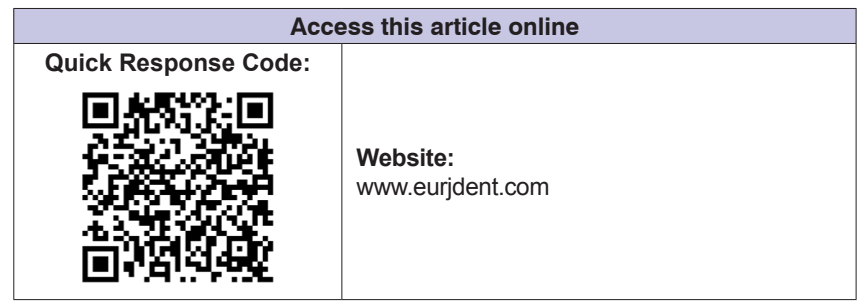

Studies by Byström and Sundqvist ${ }^{[2,3]}$ and Byström and Sunvqvist ${ }^{[4]}$ confirmed the use of $\mathrm{NaOCl}$ as an effective root canal irrigant. $\mathrm{NaOCl}$ can reduce bacterial infection better than normal saline solution (NSS). The efficiency of irrigation can be increased by adding ethylenediaminetetraacetic acid (EDTA) for smear layer elimination. $\mathrm{NaOCl}$ penetrates deeper

This is an open access article distributed under the terms of the Creative Commons Attribution-NonCommercial-ShareAlike 3.0 License, which allows others to remix, tweak, and build upon the work non-commercially, as long as the author is credited and the new creations are licensed under the identical terms.

For reprints contact: reprints@medknow.com

How to cite this article: Vajrabhaya L, Sangalungkarn V, Srisatjaluk R, Korsuwannawong S, Phruksaniyom C. Hypochlorite solution for root canal irrigation that lacks a chlorinated odor. Eur J Dent 2017;11:221-5.

DOI: 10.4103/ejd.ejd_354_16 
along the canal wall and into the dentin after EDTA irrigation. Studies investigating the use of $\mathrm{NaOCl}$ with EDTA revealed less bacterial infection than in patients in whom only $\mathrm{NaOCl}$ was used. The optimal chemical concentration of $\mathrm{NaOCl}$ is between $1 \%$ and $6 \% \cdot{ }^{[5-7]} \mathrm{NaOCl}$ and EDTA irrigation not only display antibacterial and tissue dissolution effects mentioned above but also show deep penetration in areas that are impossible for mechanical instruments to reach. Therefore, several irrigants have been recommended for canal disinfection in combination with canal preparation.

$\mathrm{NaOCl}$ is commonly used as a root canal irrigant in combination with 17\% EDTA. ${ }^{[8]}$ EDTA dissolves inorganic material and allows $\mathrm{NaOCl}$ to penetrate the smear layer for organic tissue dissolution and bacterial elimination. The disadvantage of contemporary $\mathrm{NaOCl}$ is the chlorinated odor (chlorine odor) which can be unpleasant for both dental staff and patients. The chlorine odor is released from hypochlorous acid after the reaction of $\mathrm{NaOCl}$ with water. Chlorine is a strong oxidant that inhibits bacteria through the irreversible oxidation of the sulfhydryl groups of bacterial enzymes. ${ }^{[9]}$ Fatty acids and glycerol are generated after the interaction between $\mathrm{NaOCl}$ and organic tissue. Based on these properties, $\mathrm{NaOCl}$ is the irrigant of choice for root canal treatment.

The disadvantage of contemporary $\mathrm{NaOCl}$ could be solved by preventing the evaporation of chlorine gas from $\mathrm{NaOCl}$ solutions. Adding a substance into the solution that reacts with chlorine gas is one possible strategy. However, these $\mathrm{NaOCl}$ solutions would still require the antibacterial and tissue dissolution effects to be effective for clinical use.

The aim of this study was to formulate an $\mathrm{NaOCl}$ solution with an unchlorinated odor that has similar tissue dissolution, antibacterial, and cytotoxic effects as $\mathrm{NaOCl}$ solutions already in use.

\section{MATERIALS AND METHODS}

- Formulation of a hypochlorite solution with an unchlorinated odor

- Our formulation consists of two main components.

- Component 1: Ten milliliters of trichloroisocyanurate at a final concentration of $2.5 \%(\mathrm{w} / \mathrm{v})$ was prepared from powder and was used to produce hypochlorite ions.

- Component 2: Ten milliliters of vehicle solution composed of sulfonic acid, phosphate buffer, sodium hydroxide, and deionized water was mixed with component 1 . The chemical reaction is shown in the following equation.

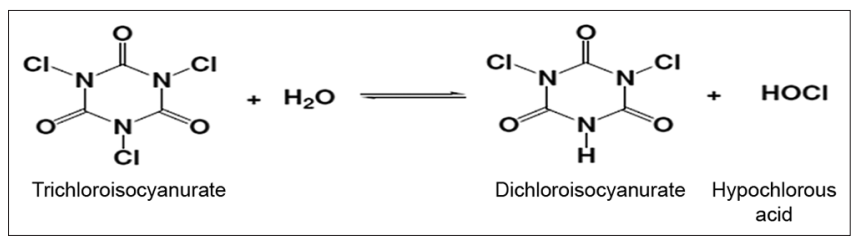

In our solution, chlorine gas that disintegrates from hypochlorous acid would be captured by the solution and reconverted to hypochlorous acid. A pilot study revealed that the hypochlorite ion content and $\mathrm{pH}$ were stable in solution after an incubation period of 4 weeks. The new formulated $\mathrm{NaOCl}$ solution was called trichloroisocyanuric acid (TCA) $3.5 \%+1 / 6$ Buffer-1.

\section{Pulpal tissue preparation}

Bovine mandibular incisor teeth were collected under a protocol approved by the Ethics Committee of Rangsit University (No. RSEC 01/2557). Teeth were stored at $-20^{\circ} \mathrm{C}$ and were thawed to room temperature before the experiment. Each tooth was split in half in the mesiodistal direction using a diamond bur. The pulpal tissue was removed, dissected, and weighed using a calibrated electronic balance (Precisa, Dietikon, Switzerland). The weight for each sample was approximately $0.1 \pm 0.005 \mathrm{~g}$.

\section{Test irrigant}

Two commercial $2.5 \% \mathrm{NaOCl}$ solutions are available in Thailand: CU from Chulalongkorn University, Bangkok, Thailand and MU from Mahidol University, Bangkok, Thailand. These solutions were used for comparison with our $2.5 \% \mathrm{NaOCl}$ solution. NSS was used as a negative control.

\section{Tissue dissolution evaluation}

Prepared bovine pulpal tissue weighing approximately $0.1 \pm 0.005 \mathrm{~g}$ was placed in contact with $20 \mathrm{ml}$ of each test irrigant in a test tube as follows:

- Group 1 TCA 3.5\% + 1/6 Buffer-1

- Group $2 \mathrm{CU} 2.5 \% \mathrm{NaOCl}$

- Group $3 \mathrm{MU} 2.5 \% \mathrm{NaOCl}$

- Group 4 NSS.

Each test tube was incubated in a $37^{\circ} \mathrm{C}$ incubator (Memmert GmbH, Schwabach, Germany). After 20 min of incubation, the pulpal tissue was removed from the test tube, blotted dry with a paper towel, and then, the remaining tissue was weighed and 
recorded. Ten parallel samples per group were incubated for all experiments. The percent pulpal tissue loss for each group was calculated using the following equation:

$\%$ Tissuedissolution $=$

Pretreatment tissue- Posttreatment tissue

Pretreatment tissue

\section{Antimicrobial activity evaluation}

Pure cultures of Enterococcus faecalis (ATCC 19433) grown on a brain-heart infusion (BHI, BD - Difco, Franklin Lakes, NJ, USA) agar plate were suspended in sterile $0.9 \% \mathrm{NaCl}$. The cell suspension was adjusted spectrophotometrically to match the turbidity of a McFarland 0.5 scale $\left(1.5 \times 10^{8} \mathrm{cfu} / \mathrm{ml}\right)$.

One milliliter of each test irrigant, including the control group (sterile saline), was placed on the bottom of the individual test tube. Two milliliters of the bacterial suspension was vortexed for $10 \mathrm{~s}$ with each test irrigant or sterile saline, and the suspension was incubated with the samples for $30 \mathrm{~s}, 1,10$, and 30 min with 6 tubes/each time period/test material. After each period of treatment time, $0.5 \mathrm{ml}$ of each tube was transferred to a tube containing $1 \mathrm{ml}$ of $\mathrm{BHI}$ and neutralizers $(0.6 \%$ sodium thiosulfate) to prevent continued antimicrobial effects of the test irrigants. All tubes were incubated at $37^{\circ} \mathrm{C}$ for 7 days to check for additional bacterial growth. The tubes presented with medium turbidity similar to the turbidity of 4 on the McFarland scale $\left(12 \times 10^{8} \mathrm{cfu} / \mathrm{ml}\right)$, which is considered positive bacterial growth.

After 7 days of incubation, $20 \mu \mathrm{l}$ of each suspension was collected from the tube and placed on a BMI agar plate to determine whether any viable bacteria remained.

\section{Cytotoxicity evaluation}

The procedure for cytotoxicity evaluation was performed according to ISO 7405: 2008 Dentistry-Evaluation of biocompatibility of medical devices used in dentistry. ${ }^{[10]}$

\section{Test materials}

TCA 3.5\% + 1/ 6 Buffer- 1, CU, and MU irrigants were diluted to $20 \%, 2 \%, 0.2 \%$, and $0.02 \%$.

As a positive control, ISO 10993-5 ${ }^{[11]}$ recommends using polyvinyl chloride (Hatano Research Institute, Food and Drug Safety Center, Kanagawa, Japan) at $3 \mathrm{~cm}^{2} / 2 \mathrm{ml}$ of media. The films were sterilized by soaking in $70 \%$ alcohol for $1 \mathrm{~min}$, washed in NSS for $1 \mathrm{~min}$, and air-dried. Then, the films were inserted into Dulbecco's Modified Eagle's Medium (DMEM) and incubated at $37^{\circ} \mathrm{C}$ under $5 \% \mathrm{CO}_{2}$ for $24 \mathrm{~h}$ before testing.

As a negative control, ISO 10993-5 $5^{[11]}$ recommends using Thermanox plastic coverslips (NUNCTM Naperville, IL, USA) at $6 \mathrm{~cm}^{2} / 2 \mathrm{ml}$ of media. Thermanox plastic coverslips were cut into small pieces, soaked in DMEM, and incubated in $5 \% \mathrm{CO}_{2}$ at $37^{\circ} \mathrm{C}$ for $24 \mathrm{~h}$ before testing.

\section{Cell culture}

We used a transformed line of mouse fibroblast L929 cells (ATCC, cell line, ECACC No. 2869501, NCTC clone 929). Cells were maintained at $37^{\circ} \mathrm{C}$ under $5 \% \mathrm{CO}_{2}$ and $100 \%$ humidity in DMEM supplemented with $10 \%$ fetal calf serum and antibiotics $(200 \mu \mathrm{g} / \mathrm{ml}$ penicillin $\mathrm{G}, 200 \mu \mathrm{g} / \mathrm{ml}$ streptomycin, $2 \mu \mathrm{g} / \mathrm{ml}$ fungizone). The medium was changed every other day. When cells reached confluency, they were detached using $0.2 \%(\mathrm{w} / \mathrm{v})$ trypsin and transferred to new culture flasks.

After sufficient growth for experimentation, the cells were trypsinized and plated in 96-well culture plates at a concentration of $1 \times 10^{4}$ cells/well. Each well contained $100 \mu \mathrm{l}$ of cell suspension, and the plates were incubated for $24 \mathrm{~h}$ at $37^{\circ} \mathrm{C}$ under $5 \% \mathrm{CO}_{2}$ to obtain a monolayer culture. After $24 \mathrm{~h}$ of incubation, the media were removed from each well. Then, $100 \mu$ l of eluate was collected from all test irrigants at concentrations of $20 \%, 2 \%, 0.2 \%$, and $0.02 \%$, and along with the positive control and negative control, the samples were added to 96-well culture plates (8 wells/test material). Following a $24-\mathrm{h}$ incubation period at $37^{\circ} \mathrm{C}$ under $5 \% \mathrm{CO}_{2}$, cell viability was assessed using an 3-(4,5-Dimethylthiazol-2-yl)-2,5-diphenyltetrazolium bromide (MTT) assay.

$3-(4,5-\mathrm{D}$ i m e th y $1 \mathrm{th}$ i a z o $1-2-\mathrm{y} 1)-2,5-$ diphenyltetrazolium bromide assay

The test materials were removed from each well. Then, $50 \mu \mathrm{l}$ of MTT reagent $(5 \mathrm{mg} / \mathrm{ml})$ was added and incubated for $2 \mathrm{~h}$ at $37^{\circ} \mathrm{C}$ in a $\mathrm{CO}_{2}$ incubator. The MTT solution was then discarded, and $100 \mu \mathrm{l}$ of isopropanol was added to the wells. The plates were incubated with shaking to solubilize the formation of the purple crystal formazan. The absorbance was measured using a microplate reader at a wavelength of $570 \mathrm{~nm}$. 


\section{RESULTS}

\section{Dissolution of bovine pulpal tissue}

The percentage of tissue loss after contact with all test irrigants for $20 \mathrm{~min}$ is shown in Figure 1. We observed no differences in the percentage of tissue loss among samples treated with our $\mathrm{NaOCl}$ solution and the commercial irrigants CU and MU $(P>0.05)$. NSS showed less tissue dissolution than all tested $\mathrm{NaOCl}$ solutions $(P=0.000)$.

\section{Antimicrobial activity evaluation}

All irrigants were effective at killing $100 \%$ of E. faecalis for all tested times (30 s, $1 \mathrm{~min}, 10 \mathrm{~min}$, and $30 \mathrm{~min}$ ). No bacterial growth occurred on BHI agar plates after 7 days of incubation for all tested irrigants.

The control group, NSS, yielded positive cultures, and E. faecalis was recovered from all positive cultures as shown in Table 1.

\section{Cytotoxicity evaluation}

The cytotoxic effects of all tested irrigants and the controls are shown in Figure 2. Percentages of cell viability were similar after contact with $20 \%$ or $2 \%$

\begin{tabular}{|c|c|c|c|c|}
\hline \multirow[t]{2}{*}{ Tested solution } & \multicolumn{4}{|c|}{ Contact time $(n=6)$} \\
\hline & $30 \mathrm{~s}$ & $1 \mathrm{~min}$ & $10 \mathrm{~min}$ & $30 \mathrm{~min}$ \\
\hline TCA 3.5\%+1/6 Buffer-1 & - & - & - & - \\
\hline CU irrigant & - & - & - & - \\
\hline MU irrigant & - & - & - & - \\
\hline NSS & + & + & + & + \\
\hline
\end{tabular}

+: Bacterial growth, -: No bacterial growth, TCA: Trichloroisocyanuric acid, NSS: Normal saline solution

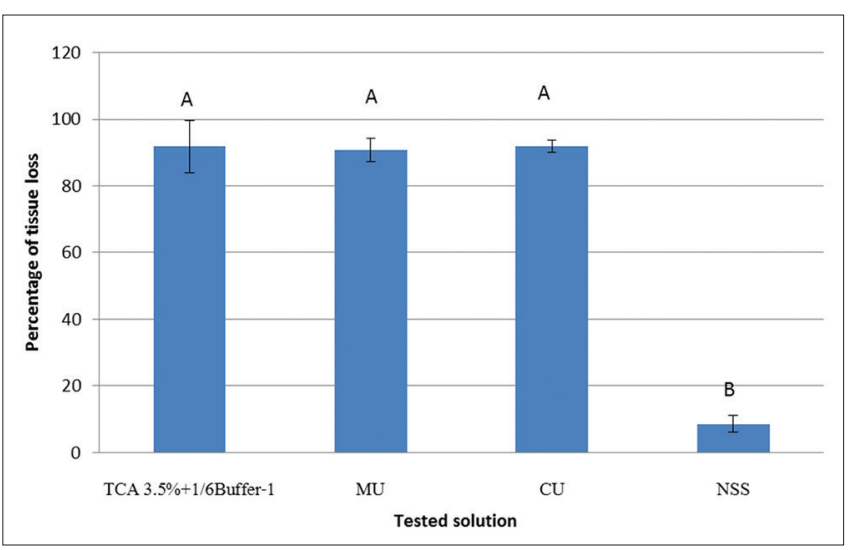

Figure 1: The percentage of tissue loss after $20 \mathrm{~min}$ of contact time (the same letter indicates $P>0.05$ ) solutions of our $\mathrm{NaOCl}$ formulation, commercial $\mathrm{NaOCl}$ (CU and MU irrigants), or positive control solution $(P>0.05)$. At the lower dilution of $0.2 \%$, all tested irrigants were more toxic than the negative control $(P=0.001)$. The lowest concentration of all tested irrigants $(0.02 \%)$ and the negative control showed similar levels of toxicity toward L929 cells $(P=1.000)$, which was less than that of the positive control solution $(P=0.001)$.

\section{DISCUSSION}

$\mathrm{NaOCl}$ is the most commonly used endodontic irrigant because of its tissue-dissolving and antibacterial activities. The new formulation of an $\mathrm{NaOCl}$ solution with an unchlorinated odor could be effectively used as a root canal irrigant to replace the original $\mathrm{NaOCl}$ solutions currently in use. Our formulation, TCA $3.5 \%+1 / 6$ Buffer- 1 , could be used in place of commercial $2.5 \% \mathrm{NaOCl}$ that is available in Thailand, as the tested properties of the new formula did not differ from those of the original solutions.

For tissue dissolution, TCA 3.5\% + 1/6 Buffer- 1 displayed similar tissue-dissolving capacity to the original solutions $(P>0.05)$. Our study reveals that the percentage of tissue loss of all tested irrigants, including our formula and both $\mathrm{CU}$ and MU, was approximately $90 \%$, whereas the control group, NSS, displayed much less tissue loss $(8 \%, P=0.000)$ Bovine pulpal tissue was selected because of its similarity to human pulpal tissue. ${ }^{[12]}$ Moore and Wesselink ${ }^{[13]}$ revealed that the amount of organic matter in relation to the amount of irrigant in the system affects the amount of tissue dissolution. Our study was standardized using a constant $20 \mathrm{ml}$ of solution (both

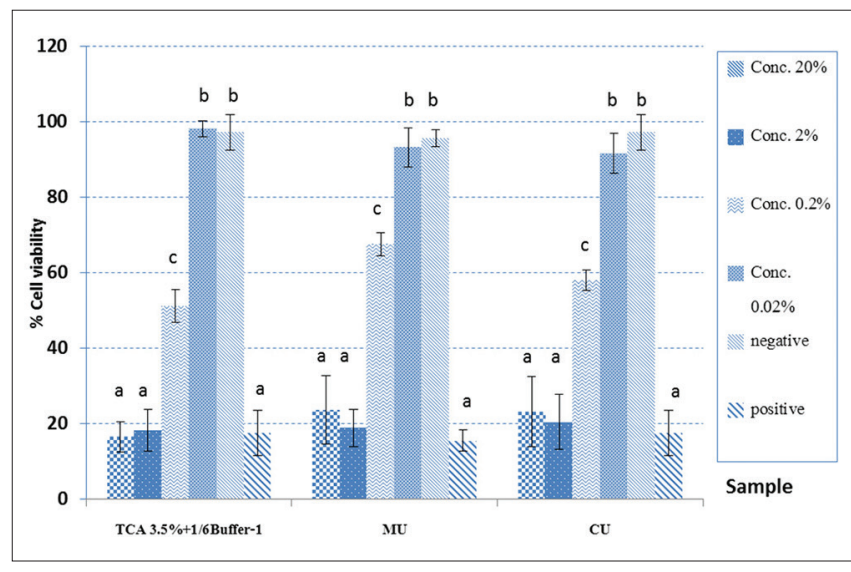

Figure 2: The percentage of viable cells after contact with the test solution at different concentrations (the same letter indicates $P>0.05$ ) 
test and control groups) in contact with $0.1 \pm 0.005 \mathrm{~g}$ bovine pulpal tissue in every group.

Several methods exist to determine the capacity of tissue dissolution of different irrigants in vitro. One method visually measures the amount of time to completely dissolve the tissue sample. A major disadvantage of this method is the difficulty associated with determining the end-point of complete dissolution as a result of solution turbidity. Therefore, we used a different method by fixing the contact time to $20 \mathrm{~min}$ for tissue dissolution and then measuring the extent of dissolution for each solution. The percentage of tissue loss was calculated based on the weights before and after exposure to the test solutions.

In addition, the antibacterial effects of TCA $3.5 \%+1 / 6$ Buffer- 1 through direct contact, which is a traditional method of measuring the antimicrobial effectiveness of endodontic irrigants with $E$. faecalis, demonstrated the same efficiency as commercial 2.5\% $\mathrm{NaOCl}$. All tested irrigants killed $100 \%$ of bacteria after $30 \mathrm{~s}$ of exposure. Although the direct contact test with planktonic bacteria does not simulate a clinical situation, these results have predictive value for ranking the effectiveness of the irrigation solutions. The biofilm model of bacterial growth may be considered in the future studies evaluating irrigation solutions. Nonetheless, our new formula and the original formulae could effectively eliminate E. faecalis, which is regularly found in endodontic cases.

The cytotoxicity evaluation of our new irrigant formula was performed according to ISO 7405:2008, dentistry evaluation of biocompatibility of medical device used in dentistry. ${ }^{[10]}$ Four different concentrations $(20 \%$, $2 \%, 0.2 \%$, and $0.02 \%$ ) were used for cytotoxicity testing. The $20 \%, 2 \%$, and $0.2 \%$ concentrations for all tested irrigants resulted in high cytotoxicity after contact with the target cells. Approximately 20\%-70\% of cells remained viable after treatment at these concentrations. In contrast, the number of viable cells was $>90 \%$ in response to $0.02 \%$ concentration of all irrigants; this survival percentage was not different from that of the negative control $(P=1.000)$ and was less cytotoxic than the positive control $(P=0.001)$. Ideally, the irrigant should not push out of the canal in clinical practice as pain and swelling could immediately occur due to extruding $\mathrm{NaOCl}$ solution from the apical foramen. ${ }^{[14]}$ The higher concentration of $\mathrm{NaOCl}$ solution is a more cytotoxic solution that affects the periapical tissue.

\section{CONCLUSIONS}

The results of this study report a new formulation of $\mathrm{NaOCl}$ solution that lacks a chlorinated odor but displays similar tissue dissolution, antibacterial, and cytotoxic effects to those of standard 2.5\% $\mathrm{NaOCl}$ irrigants. Our formula represents another option for endodontic irrigation in clinical practice. The advantage of our formula is a lack of chlorine odor, which could be unpleasant to dental staff and patients.

Financial support and sponsorship

This study was supported by the Rangsit University research fund.

\section{Conflicts of interest}

There are no conflicts of interest.

\section{REFERENCES}

1. Basvanis B, Haapasalo M. Update on endodontic irrigating solutions. Endod Topics 2012;24:74-102.

2. Byström A, Sundqvist G. Bacteriologic evaluation of the efficacy of mechanical root canal instrumentation in endodontic therapy. Scand J Dent Res 1981;89:321-8.

3. Byström A, Sundqvist G. Bacteriologic evaluation of the effect of 0.5 percent sodium hypochlorite in endodontic therapy. Oral Surg Oral Med Oral Pathol 1983;55:307-12.

4. Bystrom A, Sundqvist G. The antibacterial action of sodium hypochlorite and EDTA in 60 cases of endodontic therapy. Int Endod J 1985;18:35-40.

5. Podar R, Kulkarni GP, Dadu SS, Singh S, Singh SH. In vivo antimicrobial efficacy of $6 \%$ Morinda citrifolia, Azadirachta indica, and 3\% sodium hypochlorite as root canal irrigants. Eur J Dent 2015;9:529-34.

6. Goztas Z, Onat H, Tosun G, Sener Y, Hadimli HH. Antimicrobial effect of ozonated water, sodium hypochlorite and chlorhexidine gluconate in primary molar root canals. Eur J Dent 2014;8:469-74.

7. Siqueira JF Jr., Rôças IN, Favieri A, Lima KC. Chemomechanical reduction of the bacterial population in the root canal after instrumentation and irrigation with $1 \%, 2.5 \%$, and $5.25 \%$ sodium hypochlorite. J Endod 2000;26:331-4.

8. Vajrabhaya L, Sangalungkan V, Kamolroongwarakul R, Apai W, Limmechongchai S, Yingtanothai M. Five EDTA formulae in smear layer removed in canal instrumentation. J Dent Assoc Thai 2004;54:112-220.

9. Estrela C, Estrela CR, Barbin EL, Spanó JC, Marchesan MA, Pécora JD. Mechanism of action of sodium hypochlorite. Braz Dent J 2002;13:113-7.

10. International Organization for Standardization. Dentistry-evaluation of Biocompatibility of Medical Device Used in Dentistry. ISO 7405:2008. Geneva: International Organization for Standardization (ISO); 2008.

11. International Organization for Standardization. Biological evaluation of medical devices - Part 5: Tests for in vitro cytotoxicity. ISO 10993-5:2009. Geneva: International Organization for Standardization (ISO); 2009.

12. Koskinen KP, Meurman JH, Stenvall H. Appearance of chemically treated root canal walls in the scanning electron microscope. Scand J Dent Res 1980;88:505-12.

13. Moore WR, Wesselink PR. Factors promoting the tissue dissolving capacity of sodium hypochlorite. Int Endod J 1981;15:187-96.

14. Mehra P, Clancy C, Wu J. Formation of a facial hematoma during endodontic therapy. J Am Dent Assoc 2000;131:67-71. 